\title{
The Development Of Android Based Learning Media In Basketball Subject To Establish The Ability Of Fik Unimed Students
}

\author{
Rifqi Aufan ${ }^{1}$, Onyas Widianingsih ${ }^{2}$ and Miftahul Ihsan ${ }^{3}$ \\ \{rifqiaufan87@unimed.ac.id ${ }^{1}$, onyaswidianingsih@unimed.ac.id²,ihsanm@unimed.ac.id ${ }^{3}$ \} \\ Department of Physical Education, Health And Recreation, Faculty Of Sport Science, \\ State University Of Medan, Indonesia ${ }^{1,2,3}$
}

\begin{abstract}
In general, this research aimed to build a new powerful resource for college students which can be accessed by them whenever they want and wherever are using their android based smartphone. Furthermore, this research was also made to encourage and sharpen lecturer's creativity in order to make a learning media like downloadable application where can be easily found on play store and install that program on their android based smartphone, so there would be no more excuses for lecturers to be out of date from the latest technologies and information. This application contains tutorials of whole basic technique related to basketball, and complete guidance of basketball regulations along with signs and codes of the referee. The making of this application, which can be found and downloaded on "Playstore" by everybody, involved a number of lecturers in Faculty of Sport, Medan State University, to be instructors in the videos for delivering lessons of basketball technique. Based on the first test results of 30 students who have downloaded the application and learned from it there were 28 students $(\geq 80 \%)$ who categorized as excellent both in motoric skills and referee regulations comprehension and merely 2 students with good category. On the other hand, another class of 30 students who have not been introduced with the application gained lower score from those who have been by as many as 19 students in excellent category and 11 students in good category both in basketball basic techniques and arbitration.
\end{abstract}

Keywords: Learning Media, Smartphone Application, Android, Basketball, PJKR.

\section{Introduction}

Learning is essentially a process of interaction between students and their environment, resulting in a change in behavior towards a better direction. Many factors influence the process of interaction, such as both internal factors that come from within the individual and external factors that come from the environment. The most important task for the educators is to condition the environment to support changes in students' behavior (Mulyasa, 2008, p. 100).

Basketball learning emphasizes the provision of direct learning experiences through the development of process skills and scientific attitudes. Learning of basic technique skills in basketball and theories about refereeing in basketball can be done effectively with excellent interaction of interesting learning between educators and students. Successfulness result in achieving learning goals is strongly influenced by several factors, such as learning strategies, 
learning methods and approaches, and learning resources which can be taken from books, modules, worksheets, and medias.

Learning media can be created and designed in accordance with current technological developments. The use of instructional media assisted with technology, information and communication can also be used to facilitate the implementation of learning as desired by PP No. 32 of 2013 article 19 paragraph (1) that says Learning activities in education units are held for students as maximum as possible. Learning is essentially a process of interaction between students and their environment, resulting in a change in behavior towards a better direction. One of the ICT-assisted learning media that can be used as learning media is an android based software application which can be easily operated on students' smartphone wherever and whenever they wish.

The use of Android-based learning media is one of the applications of 21 st century learning styles (Calimag et al., 2014, p. 90). The use of this type of learning media has many potentials to help improve students' academic performance in the form of learning outcomes in the cognitive domain (Chuang \& Chen, 2007, p. 27; Jabbour, 2014, p. 2)

Smartphones and tablets and other electornic devices have some sort of power to transform the learning experience in a maximum level for students. This type of learning media allows learners to gain immense number of knowledge without being bound by time and place with interesting applications (Squire, 2009, p.70; Meister, 2011, p. 28).

Students in Medan State University, particularly who are majoring in Physical Education, Health and Recreation Unimed who have to attend practical courses, especially basketball, are required to be able to master basic skills or movements in basketball such as dribbling, passing, catching and shooting, so the number of meetings offered by the faculty is insufficient.In addition, regarding to the lack of learning hours, many other factors have resulted in the implementation of lectures not being effective and efficient.

This research aimed to develop Android-based basketball learning program in order to establish students' basic technique skills and arbitration materials, tested the feasibility of developed learning media, and examined the effect of the use of instructional media developed on improving academic performance in the form of learning motivation and learning outcomesof students in Faculty of Sport Science, Medan State University.

\section{Research methodology}

This study is a Research and Development kind that conducted to produce a product and tested the effectiveness of the product(Sugiyono, 2010, p. 407). The development model used in this study is an adaptation of the Borg \& Gall model (1983, pp. 589-594).The model adaptation results was listed in five stages of development, namely (1) information gathering, (2) product planning, (3) product development, (4) product validation, and (5) product evaluation. 


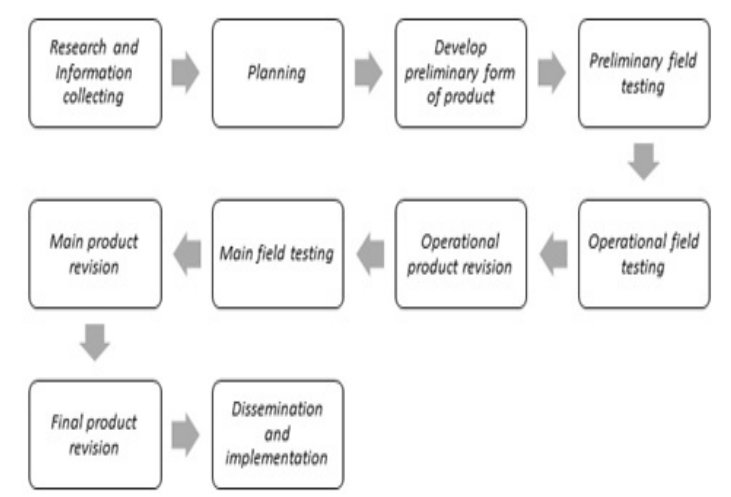

Figure 1. Research and development process (source: sugiyono (2009:85))

According to Barab and squaire, (2004) Design-based research or design experiments are a series of research approach development aimed at studying learning theory and learning theory with the aim of generating a new paradigm in the field of theory and practice that has a direct impact both in teaching and learning.

This research used survey methods, such as observation, interview, expert review and documentationto collect data. This survey method was used as the first foundation for the design of an Android-based application which used Siberian software as an application to build the Android program that will be given to students in Faculty of Sport Science, Medan State University.

This research was carried out with 5 steps from the adaptation of Borg \& Gall's development model (1983, pp. 589-594). There were five Steps taken in this study, (1) information gathering (literature study, field survey, needs analysis, curriculum analysis), (2) product planning (making flowcharts, storyboards, material texts, evaluation questions, and collecting images, sounds, and music), (3) product development, (4) product validation (material experts, media experts, peer reviewers, and chemical educators), and (5) product evaluation (individual trials, limited trials, field trials). Academic performance of students that were discussed in this study was limited to learning motivation and cognitive learning outcomes of students.

This study used quantitative and qualitative descriptive analysis techniques in terms of data analysis, depending on the type of data and the research design which was obtained. Moreover, to see the final result, a comparison was made between two classes in which one was given an android learning application while one class was not.

\section{Research result and discussion}

The first stage carried out in this research was totake all basic technical movement videos in basketball which had been designed as clearly as possible by paying a close attention to every detail that will be seen by the students later. Furthermore, not only did the tutorial video of basic technique, this android-based application also contained refereeing videos in it so that the students could learn about basketball regulation and how to lead a basketball match as a referee.After the video has been recorded, the next step was to design an Android-based learning application using Siberian Application. Videos that had been recorded were then 
entered into the application as contents that can be accessed through android-based smartphone.

The results of small group trials conducted on applications and learning videos of basic engineering exercises in basketball, which were evaluated by experts, based on the results of the analysis were obtained by experts, as shown below:

The next step after the application design and learning video content was successfully revised in second phase by the experts then the program was proceeded by testing the product to the large group of try-out field involved 30 subjects of Regular Class A PJKR students, while 30 students from the Regular PJKR class B was not introduced to this program.

Table 1. Revision by experts.

\begin{tabular}{lll}
\hline No & Revised Items & Suggestions \\
\hline 1 & Angle & $\begin{array}{l}\text { The angle of video must have been } \\
\text { recorded widely so that the details } \\
\text { will appear clearly on the screen. }\end{array}$ \\
& $\begin{array}{l}\text { The result of edited videos must } \\
\text { have at least three different angles, } \\
\text { in order to give a better perspective } \\
\text { of picture } \\
\text { Model, who played the role on the } \\
\text { video, should have been worn a } \\
\text { proper jersey to make it more } \\
\text { professional. }\end{array}$ \\
& &
\end{tabular}

Assessment data from 30 respondents / students who were giventhis android-based applications in order to maximize basketball learning outcomes on the effectiveness of basketball learning models both in basic techniques and refereeing science obtained results from students, wherethose who obtained grade score $\geq 80$ (Excellent) were 28 people and grades 60-79 (good) were 2 people, and all of them were declared PASS, as shown in the table below:

Table 2. Large Try-Out Field of Class A

\begin{tabular}{llll}
\hline Score & Category & Meaning & Total \\
\hline$\geq 80$ & Excellent & Pass & 28 \\
$60-79$ & Good & Pass & 2 \\
$30-59$ & Enough & Not Pass & 0 \\
$30-39$ & Bad & Not Pass & 0 \\
$<29$ & Worse & Not Pass & 0
\end{tabular}

Assessment data from the other class with the same amount of 30 respondents / students who were not given an android-based application to maximize their basketball learning outcomes 
on the effectiveness of basketball learning models both in basic techniques and refereeing science obtained results from students where those who obtained grades $\geq 80$ (excellent) were 19 people and grade 60-79 (good) were 11 people, as shown in the table below:

Table 3. Large Try-Out Field of Class B.

\begin{tabular}{llll}
\hline Score & Category & Meaning & Total \\
\hline$\geq 80$ & Excellent & Pass & 14 \\
$60-79$ & Good & Pass & 11 \\
$30-59$ & Enough & Not Pass & 5 \\
$30-39$ & Bad & Not Pass & 0 \\
$<29$ & Worse & Not Pass & 0 \\
\hline
\end{tabular}

therefore, the difference between Class A and B was merely 4\% even though both classes both show good results, but the percentage of class success introduced with android-based applications about basketball learning both in basic techniques and refereeing techniques was higher compared to class that was not introduced with the application.

\section{Conclusions}

Based on the results of research that has been done on students' skills in conducting basic techniques in basketball such as dribbling, passing, catching and shooting as well as refereeing in basketball both about the rules and codes of a referee the results obtained that by providing learning media in the form of android-based applications with video content to students, the results of technical skills and knowledge of the rules in the game of basketball can be increased more maximally and better than just giving conventional learning in class and field.

This difference can be proven by comparing two classes with the same level and character, namely the Regular A and B PJKR classes where class A is superior to class B as a whole. Therefore, it can be concluded that by applying learning media in the form of androidbased applications with content in the form of learning videos can improve students' abilities because they will more easily capture and digest the information contained in the video and they can easily access the content with smartphones. they go through the application and imitate and practice it in the field rather than just listening to the lecture or explanation from the lecturer concerned. 


\section{References}

[1] Achmad Iswahyudi.: Kesenjangan SMK dengan Perkembangan Iptek dan Dunia Usaha. Jurnal Dunia Guru, (2008)

[2] AECT.: Selecting Media for Learning. Washington DC. Association for Education Communication and Technology, (1997)

[3] Borg, W. R., \& Gall, M. D.: Educational research. Longman, New York (1983)

[4] Chuang, T. Y., \& Chen, W. F.: Effect of digital games on children's cognitive achievement. Journal of Multimedia. Vol. 2, pp. 27-30, US (2007)

[5] Chuang, Y. T.: Increasing learning motivation and student engagement through the technologysupported learning environment. Creative Education. pp. 1969-1978 (2014)

[6] Dorrell, Julie.: Resource Based Learning, London. Mc. Graw-Hill Book Company (1993)

[7] Heinich, Molenda, Russel, Saldino.: Instructional Media and Technologies For Learning $5^{\text {th }}$. Merril an Imprint of Prentice Hall Englewood Cliff. New Jersey, Colombus, Ohio (1996)

[8] Jabbour, K. K.: An Analysis of the effect of mobile learning on lebanse higher education. Informatics in Education. Vol. 13, pp. 1-15, (2014)

[9] Koumi, J.: Designing Video and Multimedia for Open and Flexible Learning. England. Open and Flexible Learning Series, (2006)

[10] Marisa.: Komputer dan Media Pembelajaran. Universitas Terbuka, Banten (2012)

[11]Matsuo, K., Barolli, L., Xhafa, F., Koyama, A., \& Durresi, A.: New function for stimulating learners' motivation in a web- based e-learning system. Journal of Distance Education Technologies.Vol. 6, pp. 34-40, Padang. Tesis Program Pascasarjana UNP.Padang (2008)

[12] Newby, J. D. dkk.: Instructional Technology for Teaching and Learning: Designing Instruction, Integrating Computers, and Using Media. Prentice Hall Inc, New Jersey (2000)

[13] Riyadi, S., \& Pardjono, P.: Pengembangan multimedia pembelajaran matematika berbasis komputer untuk kelas VIII SMP. Jurnal Inovasi Teknologi Pendidikan, (2014)

[14] Siagian, Riduan.: AFTA 2015 dan Ketidak Siapan Indonesia, diakses pada alamat (2014) http://analisadaily.com/news/read/afta-2015-dan-ketidaksiapan-sdm-indonesia/53995/2014/08/12

[15] Slameto..: Belajar dan Faktor-Faktor Yang Mempengaruhinya. Rineka Cipta, Jakarta(1995)

[16] Sugiyono.: Metode penelitian pendidikan pendekatan kuantitatif, kualitatif, dan R\&D. Alfabeta, Bandung (2010)

[17] Squire, K.: Mobile media learning: multiplicities of place. On the Horizon . Vol. 17, pp. 70-80. (2009)

[17] Thorn.: http:pk.ut.ac.id/jp/52sept04/52benny.html , (2006) 